\title{
GLOSY
}

\section{MIROSŁAW NESTEROWICZ}

\section{Glosa do wyroku Sadu Apelacyjnego w Katowicach z dnia 26 stycznia 2017 r., sygn., I ACa 760/16 1}

\section{TEZY}

1. Niektóre prawa pacjenta są w bardzo ścisły sposób powiązane z procesem leczenia, nakładają określone obowiązki na podmiot udzielający świadczeń zdrowotnych. Chodzi tu przede wszystkim o prawo pacjenta do świadczeń zdrowotnych udzielanych z należytą starannością, prawo pacjenta do informacji, co implikuje zgodę objaśnioną, stanowiącą także prawo pacjenta. Przywołane prawa pacjenta nierozerwalnie wiążą się z procesem leczenia i z niego wynikaja, gdyż pacjent ma prawo do uzyskania pełnej i udzielonej w przystępnej formie informacji o stanie swojego zdrowia, postawionym rozpoznaniu, proponowanych metodach leczenia, dających się przewidzieć następstwach leczenia. Z kolei tylko w przypadku przekazania tego rodzaju informacji możliwym jest udzielenie zgody objaśnionej przez pacjenta na zabieg, czy leczenie, co wszak wyłącza bezprawność działania lekarza i prowadzi do przejęcia przez pacjenta ryzyka niepowodzenia medycznego. Zatem nie jest możliwe oddzielenie wskazanych praw pacjenta od procesu leczenia, a zaniechania w tym zakresie należy kwalifikować jako zaniechania powiązane z procesem leczenia.

2. Pacjent, który doznał szkody na skutek nieprawidłowego leczenia implantologicznego przez lekarza dentystę działającego w ramach spółki z o.o. ma roszczenie bezpośrednie (actio directa) wobec ubezpieczyciela, z którym spółka zawarła umowę ubezpieczenia OC. Odpowiedzialność ubezpieczyciela sięga tak daleko, jak odpowiedzialność cywilna ubezpieczonego, obejmuje więc także zadośćuczynienie pieniężne z tytułu naruszenia praw pacjenta.

1. LEX nr 2256901. Teza druga odautorska, wynikająca z uzasadnienia wyroku Sądu Apelacyjnego. 


\section{GLOSA}

W grudniu 2013 r. powód zwrócił się do lekarza dentysty B.J. w celu przeprowadzenia leczenia uzębienia przez zastosowanie implantów. Lekarz poinformował powoda, że może przeprowadzić leczenie, które do końca miesiąca będzie zakończone. Powód zdecydował się na leczenie, lecz chciał się zapoznać z proponowaną metodą leczenia. Sam nie znalazł informacji na ten temat, a zapytany o to lekarz poinformował go, iż jest to nowatorska metoda. Poza tą informacja powód nie uzyskał żadnej innej, tak co do przebiegu leczenia, jak i ewentualnych powikłań. Przeciwnie - lekarz poinformował go, że nie ma możliwości, aby coś się nie udało. Powód nie podpisywał zgody na zabieg, choć ze względu na podwyższone ryzyko zabiegu zgoda powinna być pisemna (art. 34 ust. 1 ustawy z 5 grudnia 1996 r. o zawodach lekarza i lekarza dentysty, t.j. Dz.U. z 2018 r. poz. 617). W znieczuleniu miejscowym lekarz stomatolog usunałł powodowi 3 zęby oraz wprowadził 6 implantów. Po usunięciu szwów okazało się, że powód nie jest w stanie założyć protezy, której wcześniej używał. Ponadto powód zauważył, że gdy płukał usta, to w trakcie tej czynności woda wydostawała się nosem. Pomimo tych dolegliwości powód nie mógł skontaktować się z lekarzem. Następnie podjęte przez lekarza działania zaradcze i leczenie okazały się nieskuteczne. Wizyty były wielokrotnie przekładane. W tym czasie powód mógł spożywać tylko płynne pokarmy. Poddał się zabiegowi założenia protezy, który też nie został przeprowadzony przez lekarza skutecznie, a pojawiły się kolejne uciążliwości i dolegliwości. Powód zdecydował się na zrobienie zdjęcia panoramicznego uzębienia, aby stwierdzić, jaki jest rzeczywisty stan szczęki. Osoby, które wykonały zdjęcie, wskazały na konieczność udania się ponownie do stomatologa i zwracały uwagę na wadliwość wykonanego zabiegu. Ponieważ pozwany zaczał powoda unikać, ten poszukiwał pomocy u innych lekarzy, co nie było łatwe, gdyż nikt nie chciał się podjać leczenia naprawczego. Ostatecznie powód uzyskał pomoc innego lekarza stomatologa, jednakże leczenie było długotrwałe i bolesne. Powód w późniejszym okresie nadal odczuwał dolegliwości bólowe, miał problemy ze spożywaniem niektórych pokarmów, pojawiały się stany zapalne wymagające leczenia.

Lekarz prowadził indywidualna praktykę lekarską w ramach lekarskiej spółki z 0.0., która posiadała ubezpieczenie OC w Towarzystwie (...) SA. Trzeba wskazać, że pacjent leczący się w spółce z ograniczoną odpowiedzialnością zawiera umowę o usługi lecznicze ze spółką, niezależnie od tego, że ma prawo wyboru lekarza. W spółce z 0.o. wspólnicy nie odpowiadają osobiście za zobowiązania spółki (art. 151 § 4 k.s.h.). Nie uchyla to odpowiedzialności deliktowej każdego z lekarzy wspólników, gdy szkoda, której doznał pacjent, jest skutkiem czynu niedozwolonego ze strony konkretnego lekarza.

W związku z tym powód, opierając się na art. 822 § 4 k.c. i umowie ubezpieczenia OC, wystapił z powództwem przeciwko ubezpieczycielowi. Dochodził odszkodowania w kwocie 25.947 zł z tytułu zwrotu kosztów leczenia (art. 444 § 1 k.c.), zadośćuczynienia w kwocie 70.000 zł za krzywdę związaną z uszczerbkiem na zdrowiu (art. 445 § 1 k.c.) oraz zadośćuczynienia w kwocie 25.000 zł za naruszenie praw pacjenta w postaci godności, prywatności i autonomii pacjenta (art. 4 ust. 1 i art. 18 ust. 1 i 2 ustawy z 6 listopada 2008 r. o prawach pacjenta i Rzeczniku Praw Pacjenta, t.j. Dz.U. z 2017 r. poz. 1318 w zw. z art. 448 k.c.).

Uzasadniając roszczenie o zadośćuczynienie za naruszenie praw pacjenta powód twierdził, że jest to zadośćuczynienie za naruszenie jego prawa do rzetelnej informacji o stanie zdrowia, prawa wyboru lekarza specjalisty, metody leczenia i wyrażenia na nią świadomej zgody, naruszenia 
integralności cielesnej przez wykonanie bezprawnego zabiegu operacyjnego wszczepienia implantów zębowych bez pisemnej zgody na planowany zakres leczenia i bez udzielenia szczegółowych i prawdziwych informacji o stanie zdrowia powoda, możliwych metodach leczniczych, dających się przewidzieć następstwach ich zastosowania, wynikach leczenia oraz rokowaniu, a także braku wydania rzetelnej dokumentacji medycznej.

Równolegle do sprawy sądowej toczyło się wobec lekarza postępowanie dyscyplinarne, wszczęte przez Okręgowego Rzecznika Odpowiedzialności Zawodowej. Rzecznik wskazał na rażące nieprawidłowości w postępowaniu lekarza, brak uzyskania świadomej zgody pacjenta na leczenie i akceptacji przez niego planu leczenia oraz badań radiologicznych wykonanych przed zabiegiem, a także rentgenogramów po założeniu implantów. co pozwoliłoby lekarzowi na kontrolę wyników leczenia. Postawił lekarzowi zarzut niedołożenia należytej staranności w postępowaniu lekarskim wobec powoda, polegający na nieprawidłowym zaplanowaniu i przeprowadzeniu leczenia implanto-protetycznego (art. 4 ustawy o zawodach lekarza i lekarza dentysty i art. 8 Kodeksu Etyki Lekarskiej].

W oparciu o opinię biegłego Sąd Okręgowy ustalił, że leczenie powoda nie było prawidłowe i uwzględnił powództwo do łącznej wysokości 106.847 zł, w tym kwotę 15.000 zł z tytułu naruszenia praw pacjenta, uznając ją w świetle art. 448 k.c. za odpowiednią.

W tej części wyrok zaskarżył w apelacji pozwany ubezpieczyciel uzasadniając, że nie ponosi odpowiedzialności za naruszenie praw pacjenta, gdyż - jego zdaniem - zakresem odpowiedzialności obowiązkowego ubezpieczenia OC są objęte naruszenia będące następstwem błędu lekarskiego (przede wszystkim powstały uszczerbek na zdrowiu i szkody w związku z poniesionymi kosztami], a nie zdarzenia medyczne, określone w przepisach ustawy o prawach pacjenta i Rzeczniku Praw Pacjenta. Konsekwentnie od początku procesu podnosił przy tym, że nie zawarł z ubezpieczona spółką umowy ubezpieczenia odpowiedzialności za zdarzenia medyczne, które to ubezpieczenie było w świetle ustawy z 25 kwietnia 2011 r. o działalności leczniczej, (t.j. Dz.U. z 2018 r., poz. 160) dobrowolne?

Trzeba przypomnieć, że w świetle ustawy o prawach pacjenta i Rzeczniku Praw Pacjenta pod pojęciem zdarzenia medycznego rozumie się zakażenie pacjenta biologicznym czynnikiem chorobotwórczym, uszkodzenie ciała lub rozstrój zdrowia pacjenta albo śmierć pacjenta będące następstwem niezgodnych z aktualną wiedzą medyczną:

- diagnozy, jeżeli spowodowała ona niewłaściwe leczenie albo opóźniła właściwe leczenie, przyczyniając się do rozwoju choroby;

- leczenia, w tym wykonania zabiegu operacyjnego;

- zastosowania produktu leczniczego lub wyrobu medycznego.

System ten, odpowiedzialności za szkody będące następstwem działań (zaniechań) niezgodnych z aktualną wiedzą medyczną (a więc stanowiącą tylko obiektywny element winy lekarza, personelu medycznego] nie obejmuje więc naruszenia praw pacjenta ${ }^{3}$.

Dlatego trafnie Sąd Okręgowy przyjałł odpowiedzialność pozwanego ubezpieczyciela za naruszenie praw pacjenta w ramach ubezpieczenia OC odwołując się do postanowienia siedmiu sędziów

2. Por. M. Nesterowicz, Prawo medyczne, wyd. XI, Toruń 2016, s. 505.

3. Por. M. Nesterowicz, M. Wałachowska, Odpowiedzialność za szkody wyrzqdzone przy leczeniu w zwiqzku z nowym pozasqdowym systemem kompensacji szkód medycznych (w:) Kompensacja szkód wynikłych ze zdarzeń medycznych. Problematyka cywilnoprawna i ubezpieczeniowa (red. E. Kowalewski), Toruń 2011, s. 21. 
Sądu Najwyższego z 24 II 2006 r. (III CZP 91/05, LEX nr 180669), które głosi: „Odpowiedzialność ubezpieczyciela od odpowiedzialności cywilnej sięga tak daleko (z ograniczeniami dotyczącymi zapłaty, jako rodzaju świadczenia i sumy gwarancyjnej) jak odpowiedzialność cywilna ubezpieczonego. Jej wtórny charakter nie przeszkadza jednak wystapieniu poszkodowanego bezpośrednio przeciw ubezpieczycielowi (actio directa). Ustalenie zakresu jego zobowiązania wymaga ustalenia wpierw zakresu świadczeń, do których zobowiązany jest ubezpieczający lub inna osoba wyrządzająca szkodę objętą ubezpieczeniem odpowiedzialności cywilnej”.

Actio directa jest to roszczenie poszkodowanego skierowane bezpośrednio wobec ubezpieczyciela z tytułu umowy ubezpieczenia odpowiedzialności cywilnej (OC). Jest unormowane w art. 822 $\S 4$ k.c. Uprawniony do odszkodowania może według swojego wyboru żądać naprawienia szkody od sprawcy szkody, od jego ubezpieczyciela lub obu nich łącznie. Podmioty te sa zobowiązane wobec poszkodowanego według zasad odpowiedzialności in solidum ze względu na odmienne podstawy prawne. Z chwila powstania obowiązku odszkodowawczego sprawcy szkody - ubezpieczonego jednocześnie powstaje z mocy prawa równoległy stosunek zobowiązaniowy łạczący poszkodowanego i ubezpieczyciela. Ubezpieczyciel ma obowiązek naprawienia szkody, za która odpowiedzialność ponosi ubezpieczony, jednakże w rozmiarze określonym umowa. Poza tym ubezpieczyciel może tylko w ograniczonym zakresie podnieść wobec poszkodowanego zarzuty, które przysługiwałyby mu w stosunku do ubezpieczającego ${ }^{4}$. Przepisy wprowadzajace actio directa mają bezwzględnie obowiązujący charakter, niezależnie od tego, czy odpowiedzialność ubezpieczonego jest kontraktowa czy deliktowa i czy wynika z ubezpieczenia OC dobrowolnego czy obowiązkowego. Actio directa nie może być uchylona ani ograniczona przez strony w umowie ubezpieczenia OC, skoro przysługuje poszkodowanemu z mocy prawa ${ }^{5}$. Podkreślano to już w doktrynie i orzecznictwie francuskim od początku XX w, gdzie action directe szczególnie się rozwinęła, a w szczególności w wyroku Sądu Kasacyjnego z 14 VI 1926 r. ${ }^{6}$ Przy tym idea przewodnią ubezpieczenia OC jest nie tylko ochrona interesów majatkowych osób odpowiedzialnych za szkodę, lecz przede wszystkim ochrona interesów poszkodowanych ( np. przed ewentualna niewypłacalnościa sprawcy szkody), zwłaszcza w ubezpieczeniach obowiązkowych?

Na uwagę zasługuje także stanowisko Sądu Apelacyjnego wyjaśniające charakter praw pacjenta, a mianowicie, że niektóre prawa pacjenta (prawo do świadczeń zdrowotnych, do informacji o rozpoznaniu, metodach i następstwach leczenia, do „objaśnionej” zgody) ściśle się wiążą z leczeniem i od procesu leczenia nie mogą być oddzielone. Dlatego w razie ich zawinionego naruszenia pacjent ma prawo do zadośćuczynienia za samo naruszenie prawa pacjenta na podstawie art. 4 ust. 1 ustawy z 2008 r. o prawach pacjenta i Rzeczniku Praw Pacjenta w zw. z art. 448 k.c. niezależnie

4. Por. L. Pokorzyński, Odpowiedzialność ubezpieczyciela wobec ofiar wypadków komunikacyjnych w systemach prawnych Europy Zachodniej, Studia Ubezpieczeniowe, t. 2, Warszawa-Poznań 1975, s. 132 i n.

5. Por. M. Serwach (w:) Prawo ubezpieczeń gospodarczych (red. E. Kowalewski), Prawo ubezpieczeń gospodarczych, wyd. 3, Bydgoszcz-Toruń 2006, s. 409; H. Ciepła (w:) Kodeks cywilny. Komentarz, Tom V. Zobowiqzania. Część szczególna (red. J. Gudowski), WKP 2017; E. Gniewek, P. Machnikowski, Kodeks cywilny. Komentarz (art. 822), Legalis 2017; K. Osajda, Kodeks cywilny. Komentarz (art. 822), Legalis 2017; M. Nesterowicz, E. Kowalewski, Ubezpieczenie odpowiedzialności cywilnej a ochrona poszkodowanego, NP 7-8/1976, s. 1034 i n.

6. Zob. M. Picard, A. Besson, Les assurances terrestres en droit français, t. I, Paryż 1970, s. 552; H. Moeller, De la double nature de l'action directe (w:) Études offertes à Monsieur le Professeur André Besson, Paryż 1972, s. 132.

7. Por. M. Nesterowicz, E. Kowalewski, jw., s. 1035. 
od tego, czy doznał uszkodzenia ciała lub rozstroju zdrowia, co daje podstawę do zadośćuczynienia za doznana krzywdę z art. $445 \S 1$ k.c., gdyż są podstawy odrębne ${ }^{8}$. To uzasadniało roszczenie nie tylko wobec lekarza, lecz także wobec ubezpieczyciela z umowy ubezpieczenia OC i art. 822 § 4 k.c.

\section{Wykaz źródeł}

E. Gniewek, P. Machnikowski, Kodeks cywilny. Komentarz [art. 822], Legalis 201?

M. Nesterowicz, Prawo medyczne, wyd. XI, Toruń 2016

M. Nesterowicz, E. Kowalewski, Ubezpieczenie odpowiedzialności cywilnej a ochrona poszkodowanego, NP 7-8/1976

M. Nesterowicz, M. Wałachowska, Odpowiedzialność za szkody wyrzqdzone przy leczeniu w zwiqzku z nowym pozasqdowym systemem kompensacji szkód medycznych (w:) Kompensacja szkód wynikłych ze zdarzeń medycznych. Problematyka cywilnoprawna i ubezpieczeniowa (red. E. Kowalewski), Toruń 2011

M. Picard, A. Besson, Les assurances terrestres en droit français, t. I, Paryż 1970, s. 552; H. Moeller, De la double nature de l'action directe (w:) Études offertes à Monsieur le Professeur André Besson, Paryż 1972

L. Pokorzyński, Odpowiedzialność ubezpieczyciela wobec ofiar wypadków komunikacyjnych w systemach prawnych Europy Zachodniej, Studia Ubezpieczeniowe, t. 2, Warszawa-Poznań 1975

K. Osajda, Kodeks cywilny. Komentarz (art. 822), Legalis 201?

M. Picard, A. Besson, Les assurances terrestres en droit français, t. I, Paryż 1970, s. 552; H. Moeller, De la double nature de l'action directe (w:) Études offertes à Monsieur le Professeur André Besson, Paryż 1972,

Por. M. Serwach (w:) Prawo ubezpieczeń gospodarczych (red. E. Kowalewski), Prawo ubezpieczeń gospodarczych, wyd. 3, Bydgoszcz-Toruń 2006, s. 409; H. Ciepła (w:) Kodeks cywilny. Komentarz, Tom V. Zobowiqzania. Część szczególna (red. J. Gudowski), WKP 2017

\section{PROF. ZW. DR HAB. MIROSŁAW NESTEROWICZ -}

8. Analizę tego roszczenia w doktrynie i orzecznictwie - zob. M. Nesterowicz, Zadośćuczynienie pieniężne za naruszenie praw pacjenta (w:) Czynić postęp w prawie. Księga jubileuszowa dedykowana Profesor Birucie Lewaszkiewicz-Petrykowskiej, Łódź 2017, s. 333 i n.; M. Safjan, Kilka refleksji wokół problematyki zadośćuczynienia pieniężnego z tytułu szkody wyrzq̨dzonej pacjentom, PiM 1/2005, s. 10 i n.; U. Drozdowska, Cywilnoprawna ochrona praw pacjenta, Warszawa 2007, s. 292 i n.; M. Śliwka, Prawa pacjenta w prawie polskim na tle prawnoporównawczym, wyd. II, Toruń 2010, s. 383 i n.; N. Karczewska-Kamińska, Przymus leczenia i inne interwencje medyczne bez zgody pacjenta, Warszawa 2018, s. 397 i n. 
